\title{
Vector Autoregressive Modeling on Cases Of Malaria Based on The Tribal in Tanah Bumbu District
}

\author{
Abdul Khair'1, Sarmanu², Santi Martini' ${ }^{3}$, Bambang Widjanarko Otok ${ }^{4}$ \\ ${ }^{1}$ Health Polytechnic Banjarmasin, Ministry of Health \& Ph.D Student Faculty of Public \\ Health, Airlanga University, Surabaya \\ 2 Faculty Veterinary Medicine, Airlanga University, Surabaya, \\ ${ }^{3}$ Department of Biostatistics and Demography, Faculty of Public Health, Airlanga \\ University, Surabaya, \\ ${ }^{4}$ Laboratory of Environmental and Health Statistic, Institut Teknologi Sepuluh \\ Nopember, Surabaya, INDONESIA
}

Email: ulunkhair@gmail.com,prof.sarmanu@gmail.com, santi-m@fkm.unair.ac.id, dr.otok.bw@gmail.com

\begin{abstract}
The number of malaria in this area always has the tendency of the most compared to the city/district in South Kalimantan Province. Behavior is internalisation factor from the level of knowledge, attitudes and actions of a person who influenced by customs, customs and belief in certain things that has been handed down by his ancestors. The behavior of a community group can be different from the other groups so that they formed a group behavior or can be said tribal behavior.The purpose of this research predicts that the number of the prevalence of malaria in Tanah Bumbu tribal based with $Y_{1 t}$ : the tribe of Banjar, $Y_{2 t}$ : Javanese, $Y_{3 t}$ : the tribe of Bugis, and $\mathrm{Y}_{4 \mathrm{t}}$ : other tribes using vector autoregressive (VAR) model. The results of the study showed with Granger Causality approach there is a relationship between the amount of the prevalence of Malaria Javanese with other tribes, Bugis tribe with other tribes. The relationship is strengthened in the VAR model, which is the number of the prevalence of Malaria Javanese influenced by the number of the prevalence of Malaria Javanese at period $t-1$, and the number of the prevalence of Malaria tribe Bugis at period $\mathrm{t}-1$. While the number of the prevalence of Malaria tribe Bugis influenced by the number of the prevalence of Malaria Other tribes in the period $\mathrm{t}-2$. The Model of divination the prevalence of Malaria based on ethnicity as follows:

$Y_{1 t}-Y_{1 t-1}=0.325 Y_{1 t-1}+0.277 Y_{1 t-2}+0.198 Y_{2 t-1}+0.302 Y_{2 t-2}+0.645 Y_{3 t-1}-0.955 Y_{3 t-2}-1.732 Y_{4 t-1}+0.812 Y_{4 t-2}$ $Y_{2 t}-Y_{2 t-1}=-0.085 Y_{1 t-1}+0.347 Y_{1 t-2}+0.419 Y_{2 t-1}-0.059 Y_{2 t-2}+0.844 Y_{3 t-1}-0.525 Y_{3 t-2}-0.125 Y_{4 t-1}-0.501 Y_{4 t-2}$ $Y_{3 t}-Y_{3 t-1}=-0.041 Y_{1 t-1}+0.125 Y_{1 t-2}+0.136 Y_{2 t-1}-0.181 Y_{2 t-2}+0.318 Y_{3 t-1}-0.074 Y_{3 t-2}-0.399 Y_{4 t-1}+0.653 Y_{4 t-2}$ $Y_{4 t}-Y_{4 t-1}=-0.019 Y_{1 t-1}+0.026 Y_{1 t-2}+0.101 Y_{2 t-1}+0.014 Y_{2 t-2}+0.136 Y_{3 t-1}-0.096 Y_{3 t-2}-0.075 Y_{4 t-1}-0.039 Y_{4 t-2}$
\end{abstract}

The ability of divination number of the prevalence of malaria based on the tribal areas with the criteria MAPE provides good performance of 28.5 percent.

Keywords: Malaria, Tanah Bumbu, VAR, Tribe Banjar, Javanese, Tribe Bugis, Other Tribes

\section{INTRODUCTION}

Genesis malaria of course is associated with the existence of contact with the mosquito Anopheles as penular. Some of the factors that related with the possibility of contact between people in a place with the mosquito namely characteristics, climate 
change, behavior, socio-economic conditions and others. Malaria is one of the infectious disease caused by the Plasmodium. However as other communicable disease, infection of malaria is very influenced by many factors. The things that related with the environment, behavior, and mosquitoes usually most discussed in the transmission of malaria in a region. Various researches have been done. Most research related to the mosquito Anopheles [1]. The types of mosquitoes is indeed the gnats penular known to play a role in the transmission of malaria from one person to another. modeling the relevance of these factors in the genesis of malaria on a certain period used vector autoregressive approach (VAR) [2].

VAR model was built in order to catch the phenomenon that is with good. VAR nonstructural is a model of the relations between the variables, while cointegration and Vector Error Correction Models (VECM) is a solution to create a model that has a long and short term are relationships of variables which have the problem of nonstationary [3]. VAR has several benefits such as (1) this method is simple, researchers do not need to determine where the endogenous variable and which exogenous variable because all the variables in the VAR is the endogenous variable; (2) estimation method can use Ordinary Least Square (OLS) and can be done for each equation separately; (3) the result of divination with this method in many cases better than divination with a complex simultaneous equation method [4].

South Kalimantan Province, if reviewed number from the diversity of Genesis Malaria 2011, a province with the number of Malaria sixth largest. The number of Malaria absolutely 2011 in South Kalimantan Province as much as 6663 Genesis [5]. If compared to the year 2007, then the incidence of malaria 2013 in South Kalimantan Province. Tanah Bumbu is endemic areas malaria because in the last 3 years (2011 until 2013) always found cases of malaria. The number of malaria in this area always has the tendency of the most compared to the city/another district in South Kalimantan Province. The discovery of cases of malaria in Tanah Bumbu on 2012 totaled 6044 cases from the total 29212 cases in South Kalimantan [6].

The results of research related to the genesis of malaria are the temperature and humidity in research [7], [8], [9], and [10]. The height of the location in research [7] and [11]. Biological environment in research [12] and [1]. The socio-economic research in the [12], [13], [14] and [1]. The behavior in research [15], [12], [16], [17], [18] and [19]. The status of the population in research [13], [20] and [1]. Research and modeling of divination genesis diseases including done by [21], [22] and [23]. However, model of divination that obtained in the three research is considering only the case of previously according to time and location as the variable wizards (predictors). Based on the need to be examined the predictions of malaria cases in the district of the land of spices that based on ethnicity and behavior with a model VAR.

\section{METHODS}

The Unit of analysis in this research is data number of Genesis malaria per month according to the sub-districts which are recorded in the system of recording and reporting on the health of Tanah Bumbu year 2012-2015. The basic concept in epidemiology often termed the trias epidemiology provides the relationship between the three main factors that have a role in a disease and other health problems, namely host, agent, and environment. The three factors is a dynamic unity in the balance (equilibrium) on the healthy. If the balance is disrupted, will cause the status of the sick [24]. Based on the research and theoretical studies description, then the framework of 
the concept of the research is presented in Figure 1.

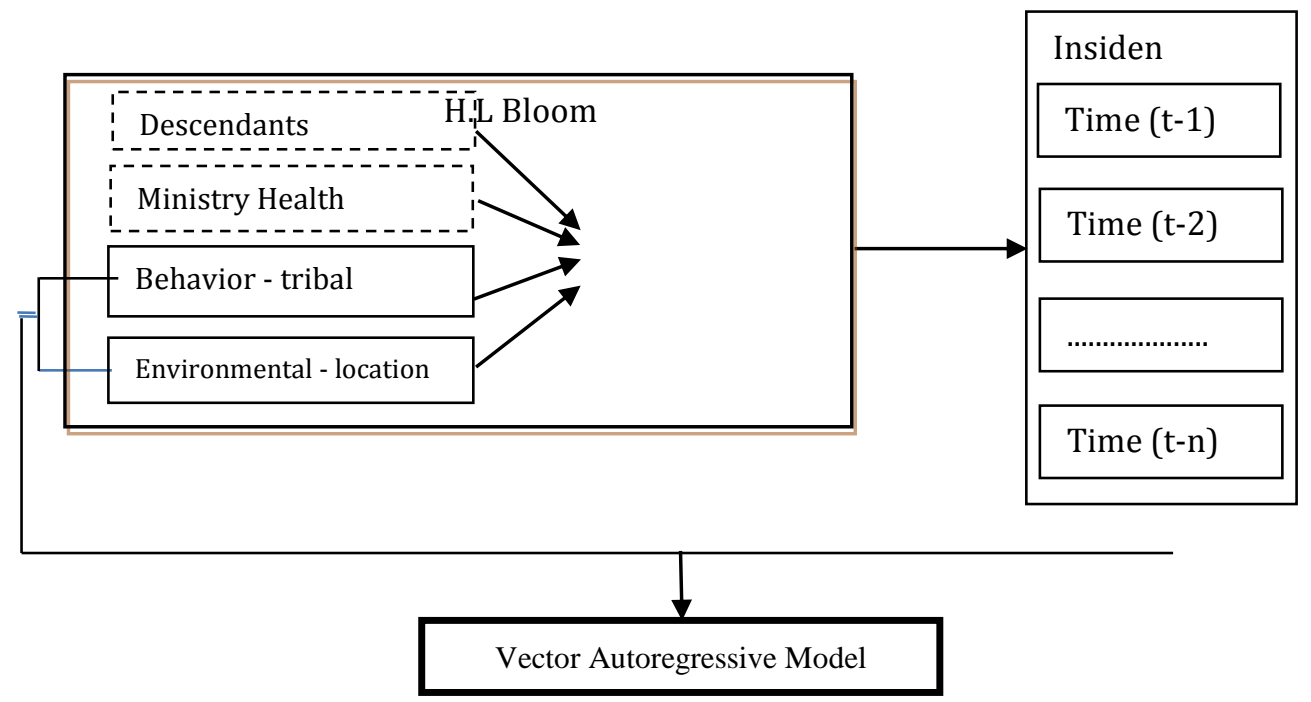

Figure 1. The Conceptual Framework of Genesis Malaria based on the tribal areas with Vector Autoregressive Model [24]

Genesis malaria can had been modeled according to the theory of H.L. 'S taxonomy. In the theory of Genesis a disease can be influenced by 4 (four) factors, factors, descendants of health services, the behavior and the environment. Specific locations have certain environmental factors that can be different from the other locations. So the variables can be used as location) are typical of a genesis pain. Incidents or genesis a disease according to the time will be able to form a specific model. The model can be used to predict the future events that will come. Community groups in Tanah Bumbu become heterogeneous community groups that can have a specific tribal behavior. This tribal behavior patterns will be used in the development of the model VAR in predicting genesis malaria in Tanah Bumbu.

Analysis steps on the modeling VAR as follows [25], [26]:

1. Pre-processing data in the tribal areas of Tanah Bumbu include month and year.

2. Test stationary in variance and the average

Stationary data is data that is not experience growth or decline. Stationary Data have a horizontal pattern along the time axis, or fluctuations in the data is located around an average value a constant, not depending on time and varians from fluctuations remain constant each time.

3. Do the identification of the model to obtain the Vector Autoregressive order (VAR)

The first model Identifkasi determine $p$ order from $\operatorname{VAR}(p)$, and then $q$ order from X. The determination of the prevailing from VAR(p) used MPACF plots and AIC minimum without involving exogenous variable. While the determination of order $\mathrm{X}$ involving exogenous variable. The value of the AIC as follows: (Wei, 2006)

$\operatorname{AIC}(p)=\ln \left(\left|\widehat{\Sigma}_{p}\right|\right)+\frac{2 m^{2} p}{n}$

Where: 
$\widehat{\Sigma}_{p}=\frac{1}{n} \sum_{t=1}^{n} \widehat{\mathbf{u}}_{t}\left(\widehat{\mathbf{u}}_{t}\right)^{\prime}$ Is based on the model residual kovarian penduga $\operatorname{VAR}(\mathrm{p})$,

$\widehat{\mathbf{u}}_{t}$ Is a residual on the time to the $\mathrm{t}$ model $\operatorname{VAR}(\mathrm{p})$

$\mathrm{M}$ is the number of endogenous variables in the model.

4. Perform the estimation of model parameters VAR used the smallest square method

5. To test the significance of model parameters VAR

6. Checking the assumption of White Noise, Normal Multivariate on a residual

7. Perform data forecasts out sample

\section{RESULTS AND DISCUSSION}

Unit will analysis in this research is data number of Genesis malaria per month according to the sub-districts which are recorded in the system of recording and reporting on the health of Tanah Bumbu year 2014-2017. Genesis malaria seen according to each of the tribal areas on all months starting January the year 2014 until May 2017 is shown in Table 1. Genesis plots Timeseries Malaria based on ethnicity served as follows:

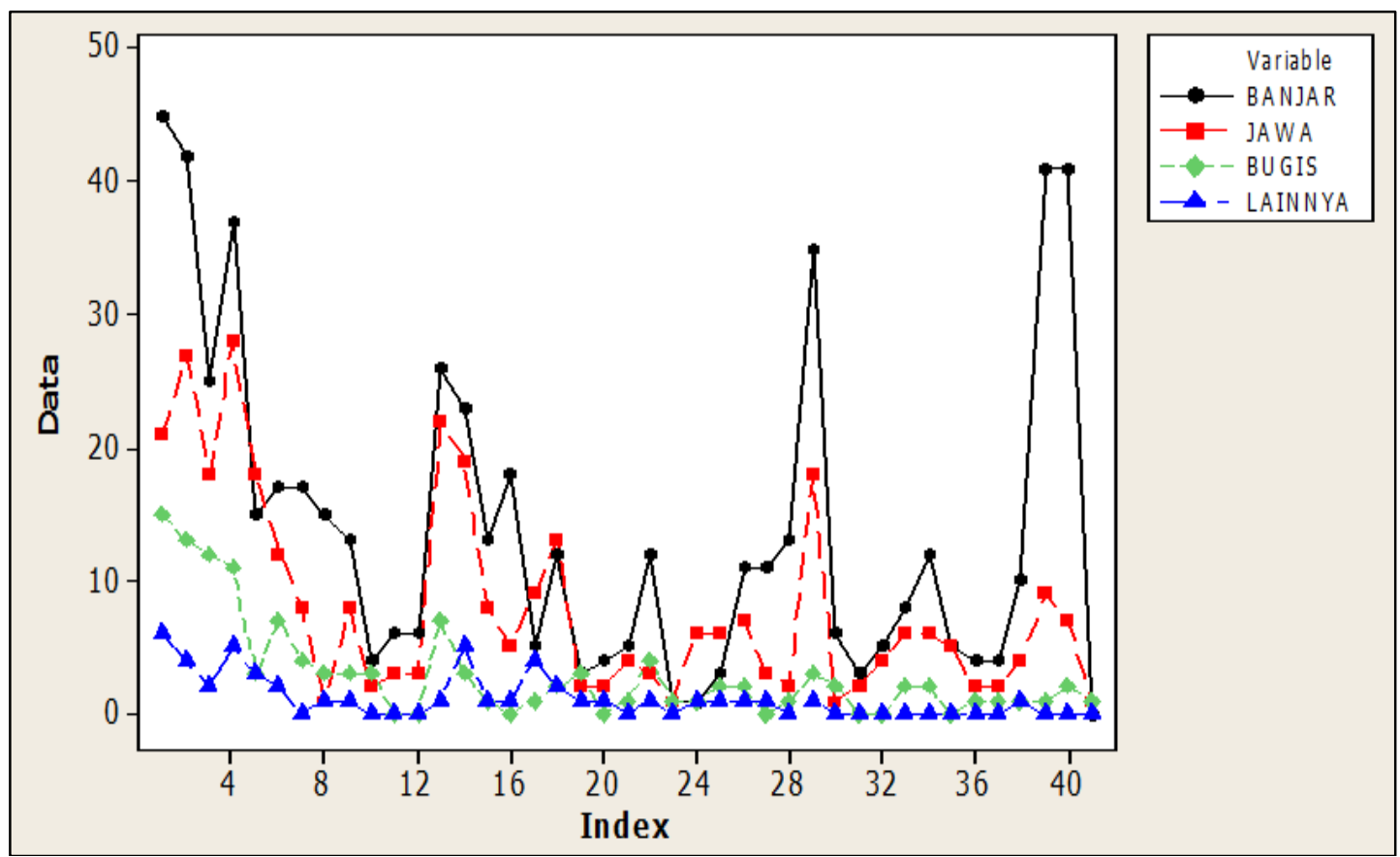

Figure 2. Genesis plots Timeseries Malaria Tribal Based

Figure 2 shows the pattern of the number of the prevalence of malaria from 41 observations on the tribe of Banjar, Java, Bugis and other tribes have the trend is down, although on the other tribes paring losses more entry ramp. This can be in it that the pattern of Genesis malaria tends to be uniform from the four tribes. 
In detail is presented in Table 1 below.

Table 1. Cross-tabulation of Genesis Malaria in Tanah Bumbu according to the years, the month and the tribal areas

\begin{tabular}{|c|c|c|c|c|c|c|c|c|c|}
\hline \multirow{3}{*}{ The Year } & \multirow{3}{*}{ The Month } & \multicolumn{8}{|c|}{ Tribal Areas } \\
\hline & & \multicolumn{2}{|c|}{ Banjar } & \multicolumn{2}{|c|}{ Central Java } & \multicolumn{2}{|c|}{ Bugis } & \multicolumn{2}{|c|}{ Others } \\
\hline & & $\mathrm{f}$ & $\%$ & $\mathrm{f}$ & $\%$ & $f$ & $\%$ & $\mathrm{f}$ & $\%$ \\
\hline 2014 & January & 45 & 51.7 & 21 & 24.1 & 15 & 17.2 & 6 & 6.9 \\
\hline 2014 & February & 42 & 48.8 & 27 & 31.4 & 13 & 15.1 & 4 & 4.7 \\
\hline 2014 & March & 25 & 43.9 & 18 & 31.6 & 12 & 21.1 & 2 & 3.5 \\
\hline 2014 & April & 37 & 45.7 & 28 & 34.6 & 11 & 13.6 & 5 & 6.2 \\
\hline 2014 & Mei & 15 & 38.5 & 18 & 46.2 & 3 & 7.7 & 3 & 7.7 \\
\hline 2014 & June & 17 & 44.7 & 12 & 31.6 & 7 & 18.4 & 2 & 5.3 \\
\hline 2014 & July & 17 & 58.6 & 8 & 27.6 & 4 & 13.8 & 0 & 0.0 \\
\hline 2014 & August & 15 & 75.0 & 1 & 5.0 & 3 & 15.0 & 1 & 5.0 \\
\hline 2014 & September & 13 & 52.0 & 8 & 32.0 & 3 & 12.0 & 1 & 4.0 \\
\hline 2014 & October & 4 & 44.4 & 2 & 22.2 & 3 & 33.3 & 0 & 0.0 \\
\hline 2014 & November & 6 & 66.7 & 3 & 33.3 & 0 & 0.0 & 0 & 0.0 \\
\hline 2014 & December & 6 & 66.7 & 3 & 33.3 & 0 & 0.0 & 0 & 0.0 \\
\hline 2015 & January & 26 & 46.4 & 22 & 39.3 & 7 & 12.5 & 1 & 1.8 \\
\hline 2015 & February & 23 & 46.0 & 19 & 38.0 & 3 & 6.0 & 5 & 10.0 \\
\hline 2015 & March & 13 & 56.5 & 8 & 34.8 & 1 & 4.3 & 1 & 4.3 \\
\hline 2015 & April & 18 & 75.0 & 5 & 20.8 & 0 & 0.0 & 1 & 4.2 \\
\hline 2015 & Mei & 5 & 26.3 & 9 & 47.4 & 1 & 5.3 & 4 & 21.1 \\
\hline 2015 & June & 12 & 41.4 & 13 & 44.8 & 2 & 6.9 & 2 & 6.9 \\
\hline 2015 & July & 3 & 33.3 & 2 & 22.2 & 3 & 33.3 & 1 & 11.1 \\
\hline 2015 & August & 4 & 57.1 & 2 & 28.6 & 0 & 0.0 & 1 & 14.3 \\
\hline 2015 & September & 5 & 50.0 & 4 & 40.0 & 1 & 10.0 & 0 & 0.0 \\
\hline 2015 & October & 12 & 60.0 & 3 & 15.0 & 4 & 20.0 & 1 & 5.0 \\
\hline 2015 & November & 1 & 33.3 & 1 & 33.3 & 1 & 33.3 & 0 & 0.0 \\
\hline 2015 & December & 1 & 11.1 & 6 & 66.7 & 1 & 11.1 & 1 & 11.1 \\
\hline 2016 & January & 3 & 25.0 & 6 & 50.0 & 2 & 16.7 & 1 & 8.3 \\
\hline 2016 & February & 11 & 52.4 & 7 & 33.3 & 2 & 9.5 & 1 & 4.8 \\
\hline 2016 & March & 11 & 73.3 & 3 & 20.0 & 0 & 0.0 & 1 & 6.7 \\
\hline 2016 & April & 13 & 81.3 & 2 & 12.5 & 1 & 6.3 & 0 & 0.0 \\
\hline 2016 & Mei & 35 & 61.4 & 18 & 31.6 & 3 & 5.3 & 1 & 1.8 \\
\hline 2016 & June & 6 & 66.7 & 1 & 11.1 & 2 & 22.2 & 0 & 0.0 \\
\hline 2016 & July & 3 & 60.0 & 2 & 40.0 & 0 & 0.0 & 0 & 0.0 \\
\hline 2016 & August & 5 & 55.6 & 4 & 44.4 & 0 & 0.0 & 0 & 0.0 \\
\hline 2016 & September & 8 & 50.0 & 6 & 37.5 & 2 & 12.5 & 0 & 0.0 \\
\hline 2016 & October & 12 & 60.0 & 6 & 30.0 & 2 & 10.0 & 0 & 0.0 \\
\hline 2016 & November & 5 & 50.0 & 5 & 50.0 & 0 & 0.0 & 0 & 0.0 \\
\hline 2016 & December & 4 & 57.1 & 2 & 28.6 & 1 & 14.3 & 0 & 0.0 \\
\hline 2017 & January & 4 & 57.1 & 2 & 28.6 & 1 & 14.3 & 0 & 0.0 \\
\hline 2017 & February & 10 & 62.5 & 4 & 25.0 & 1 & 6.3 & 1 & 6.3 \\
\hline 2017 & March & 41 & 80.4 & 9 & 17.6 & 1 & 2.0 & 0 & 0.0 \\
\hline 2017 & April & 41 & 82.0 & 7 & 14.0 & 2 & 4.0 & 0 & 0.0 \\
\hline 2017 & Mei & 0 & 0.0 & 1 & 50.0 & 1 & 50.0 & 0 & 0.0 \\
\hline & Total & 577 & 53.9 & 328 & 30.6 & 119 & 11.1 & 47 & 4.4 \\
\hline
\end{tabular}

Table 1 shows that the Genesis Malaria on the tribe of Banjar each month is relatively always higher than genesis malaria on the other tribes. When compared with the other tribes, then genesis malaria on the tribe of Banjar the average range between 11.1 percent to $82.0 \%$.

Now the variables used are:

The tribe of Banjar $\left(\mathrm{Y}_{1 \mathrm{~T}}\right)$ : the number of the prevalence of Malaria Tribe of Banjar against all the tribes in Tanah Bumbu

The tribe of Central Java (Y2T): the number of the prevalence of Malaria Javanese against all the tribes in Tanah Bumbu

The tribe of Bugis origin $\left(\left(\mathrm{Y}_{3 т}\right)\right.$ : the number of the prevalence of Malaria Tribe Bugis 
against all the tribes in Tanah Bumbu

Other tribes (Y $\left.{ }_{4 \mathrm{~T}}\right)$ : the number of the prevalence of Malaria Tribes besides (Banjar, Java, Bugis) against all the tribes in Tanah Bumbu.

Next time series plots, ACF and PACF each research variables presented in Figure 3.
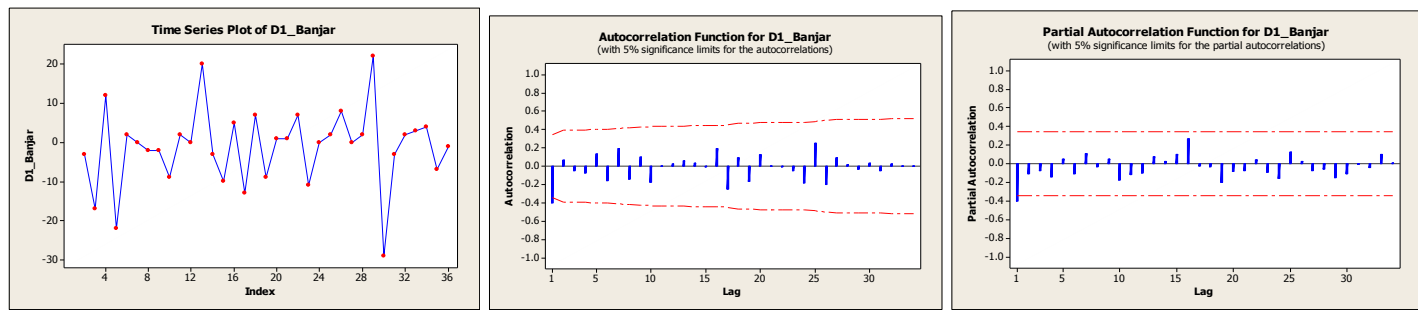

a) The tribe of Banjar
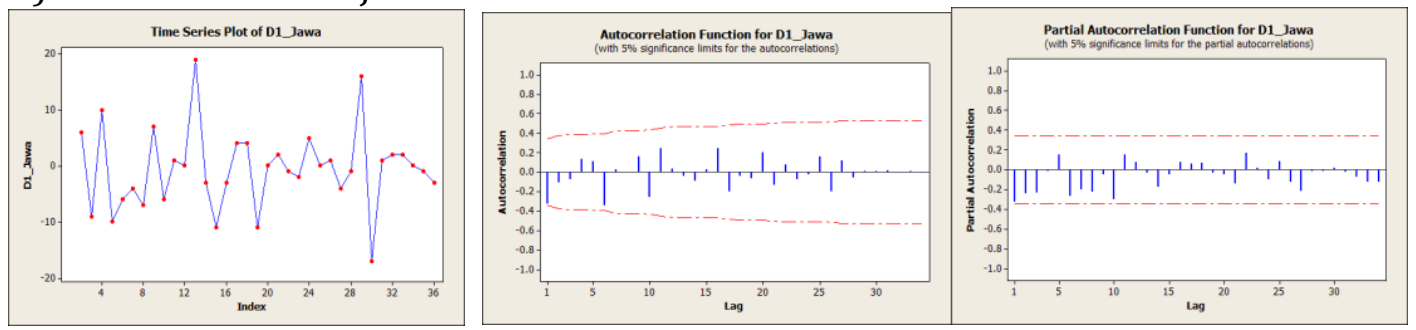

b) Javanese

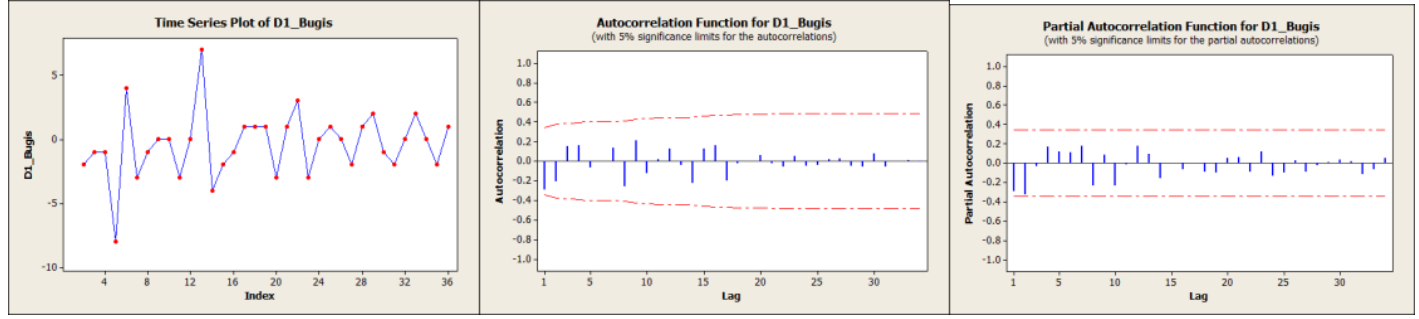

c) The tribe of Bugis

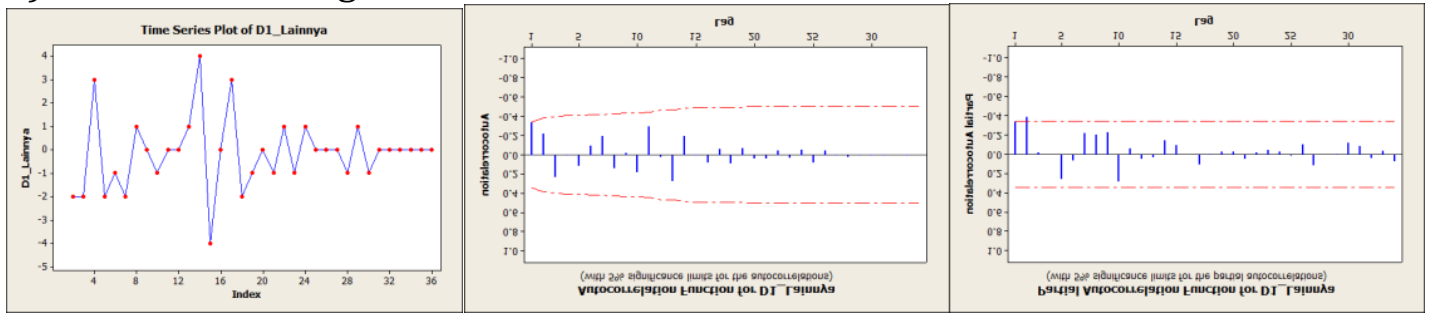

d) Other tribes

Figure 3. ACF and PACF plots Differencing 1 Prevalence of Malaria based on ethnicity

Based on the Figure 3 shows that the number of patients with Malaria tribes (Banjar, Java, Bugis, others) form the pattern that stationary on timeseries plots, while on the ACF and PACF plots there is a lag that out of bounds. It can be said that the data the number of patients with Malaria Other tribes stationary in the average and variance. The test stationary through Augmented Dickey-Fuller presented in the following table. 
Table 2. The value of the Augmented Dickey-Fuller test statistic

\begin{tabular}{lccc}
\hline The tribe of & T-Statistic & Prob & Decision \\
\hline Banjar & -3.812047 & 0.0063 & Reject H0 \\
Java & -3.251855 & 0.0252 & Reject H0 \\
Bugis & -3.624860 & 0.0104 & Reject H0 \\
Others & -4.238311 & 0.0021 & Reject H0 \\
\hline
\end{tabular}

Table 2 shows that the Prob. on all tribes (Banjar, Java, Bugis, others) smaller than $\alpha=0.05$, which means giving the decision Reject Ho. It can be said that the number of the prevalence of malaria on the tribe of Banjar, Javanese, Bugis tribe and other tribes have been stationary in mean and varians. Furthermore, done causalitas granger tests, presented in Table 3.

Table 3. Granger Causality Test

\begin{tabular}{lccc}
\hline Null Hypothesis & Obs & F-Statistic & Prob. \\
\hline Java does not Granger Cause BANJAR & 34 & 0.13943 & 0.8704 \\
BANJAR does not Granger Cause JAVA & & 0.83067 & 0.4459 \\
BUGIS does not Granger Cause BANJAR & 34 & 0.86838 & 0.4303 \\
BANJAR does not Granger Cause BUGIS & & 0.28776 & 0.7521 \\
Others does not Granger Cause BANJAR & \multirow{3}{*}{34} & 0.76900 & 0.4727 \\
BANJAR does not Granger Cause OTHERS & & 1.58712 & 0.2218 \\
BUGIS does not Granger Cause JAVA & 34 & 1.41222 & 0.2599 \\
Java does not Granger Cause BUGIS & & 0.10857 & 0.8975 \\
Others does not Granger Cause JAVA & 34 & 0.04465 & 0.9564 \\
Java does not Granger Cause OTHERS & & 3.03627 & 0.0635 \\
Others does not Granger Cause BUGIS & 34 & 1.42283 & 0.2574 \\
BUGIS does not Granger Cause OTHERS & & 2.74853 & 0.0807 \\
\hline
\end{tabular}

Table 3. shows that with the level of the significance $\alpha=10 \%$, value Prob. smaller than ten percent is the number of the prevalence of Malaria Javanese with other tribes and tribal Bugis with other tribes. This shows that there is the influence between the number of the prevalence of Malaria Javanese with other tribes and the number of the prevalence of Malaria tribe Bugis with other tribes.

Next, done modeling VAR in the tribe of Banjar (Y1T), Javanese (Y2T), the tribe of Bugis origin (Y3T), and other tribes (Y4T), which is presented in the following table. 
Table 4. The value of the Estimator, Standard deviation, t-Statistics VAR Model number of the prevalence of Malaria based on ethnicity

\begin{tabular}{|c|c|c|c|c|}
\hline & The tribe of Banjar $\left(\mathrm{Y}_{1 \mathrm{t}}\right)$ & Javaness (Y $2 \mathrm{t})$ & The tribe of Bugis $\left(\mathrm{Y}_{3 \mathrm{t}}\right)$ & Other tribes $\left(\mathrm{Y}_{4 \mathrm{t}}\right)$ \\
\hline \multirow{3}{*}{ The tribe of Banjar $\left(\mathrm{Y}_{1 \mathrm{t}-1)}\right.$} & 0.325115 & -0.085934 & -0.041048 & -0.019274 \\
\hline & $(0.33166)$ & $(0.24043)$ & $(0.07731)$ & $(0.04538)$ \\
\hline & [0.98027] & {$[-0.35742]$} & {$[-0.53094]$} & {$[-0.42472]$} \\
\hline \multirow{3}{*}{ The tribe of Banjar $\left(\mathrm{Y}_{1 \mathrm{t}-2)}\right.$} & 0.277228 & 0.346611 & 0.124575 & 0.026518 \\
\hline & $(0.31300)$ & $(0.22690)$ & $(0.07296)$ & $(0.04283)$ \\
\hline & {$[0.88572]$} & {$[1.52756]$} & [1.70739] & [0.61919] \\
\hline \multirow{3}{*}{ The tribe of Central Java (Y $\mathrm{Y}_{2 \mathrm{t}-1)}$} & 0.198695 & 0.418743 & 0.136616 & 0.101222 \\
\hline & $(0.56290)$ & $(0.40807)$ & $(0.13122)$ & $(0.04702)$ \\
\hline & {$[0.35298]$} & {$[1.02616]$} & {$[1.04115]$} & [2.15274] \\
\hline \multirow{3}{*}{ The tribe of Central Java $\left(\mathrm{Y}_{2 \mathrm{t}-2)}\right.$} & 0.302650 & -0.059674 & -0.181024 & 0.013926 \\
\hline & $(0.46587)$ & $(0.33773)$ & $(0.10860)$ & $(0.06375)$ \\
\hline & {$[0.64964]$} & {$[-0.17669]$} & {$[-1.66691]$} & {$[0.21846]$} \\
\hline \multirow{3}{*}{ The tribe of Bugis $\left(\mathrm{Y}_{3 \mathrm{t}-1)}\right.$} & 0.645513 & 0.843973 & 0.317533 & 0.136022 \\
\hline & $(0.90863)$ & $(0.65870)$ & $(0.21181)$ & $(0.06853)$ \\
\hline & {$[0.71042]$} & [1.28127] & [1.49916] & [1.98485] \\
\hline \multirow{3}{*}{ The tribe of Bugis $\left(\mathrm{Y}_{3 \mathrm{t}-2)}\right.$} & -0.955027 & -0.525865 & 0.074744 & -0.096987 \\
\hline & $(0.84783)$ & $(0.61463)$ & $(0.19764)$ & $(0.11601)$ \\
\hline & {$[-1.12643]$} & {$[-0.85558]$} & {$[0.37819]$} & {$[-0.83603]$} \\
\hline \multirow{3}{*}{ Other tribes $\left(\mathrm{Y}_{4 \mathrm{t}-1)}\right.$} & -1.731879 & -0.124645 & -0.399394 & -0.074635 \\
\hline & $(1.85035)$ & $(1.34139)$ & $(0.43133)$ & $(0.25318)$ \\
\hline & {$[-0.93597]$} & {$[-0.09292]$} & {$[-0.92596]$} & {$[-0.29479]$} \\
\hline \multirow{3}{*}{ Other tribes $\left(\mathrm{Y}_{4 \mathrm{t}-2)}\right.$} & 0.811660 & -0.501651 & 0.653682 & -0.039508 \\
\hline & $(1.55322)$ & $(1.12599)$ & $(0.32207)$ & $(0.21253)$ \\
\hline & {$[0.52257]$} & {$[-0.44552]$} & [2.02962] & {$[-0.18590]$} \\
\hline R-squared & 0.230273 & 0.299488 & 0.585486 & 0.361856 \\
\hline
\end{tabular}

Table 4 shows that the results of the estimation of VAR models with lag two monthly provide the determination coefficient value for the equation number of the prevalence of Malaria based on ethnicity dimasing of each tribe is the tribe of Banjar (0.230), Javanese (0.299), the tribe of Bugis (0.585), and other tribes (0.362). This indicates that the variables are not yet strong enough to explain the fluctuations in the number of the prevalence of Malaria. This is because the fluctuations in the number of variables the prevalence of Malaria was influenced by many good variables that originate from external and internal, for example the factors behavior. Model VAR based on ethnicity as follows.

$$
\begin{aligned}
& Y_{1 t}-Y_{1 t-1}=0.325 Y_{1 t-1}+0.277 Y_{1 t-2}+0.198 Y_{2 t-1}+0.302 Y_{2 t-2}+0.645 Y_{3 t-1}-0.955 Y_{3 t-2}-1.732 Y_{4 t-1}+0.812 Y_{4 t-2} \\
& Y_{2 t}-Y_{2 t-1}=-0.085 Y_{1 t-1}+0.347 Y_{1 t-2}+0.419 Y_{2 t-1}-0.059 Y_{2 t-2}+0.844 Y_{3 t-1}-0.525 Y_{3 t-2}-0.125 Y_{4 t-1}-0.501 Y_{4 t-2} \\
& Y_{3 t}-Y_{3 t-1}=-0.041 Y_{1 t-1}+0.125 Y_{1 t-2}+0.136 Y_{2 t-1}-0.181 Y_{2 t-2}+0.318 Y_{3 t-1}-0.074 Y_{3 t-2}-0.399 Y_{4 t-1}+0.653 Y_{4 t-2} \\
& Y_{4 t}-Y_{4 t-1}=-0.019 Y_{1 t-1}+0.026 Y_{1 t-2}+0.101 Y_{2 t-1}+0.014 Y_{2 t-2}+0.136 Y_{3 t-1}-0.096 Y_{3 t-2}-0.075 Y_{4 t-1}-0.039 Y_{4 t-2}
\end{aligned}
$$

To view the model stability, used the criteria of the value of the root of modulus less than 1. Modulus values from the VAR model is presented in the following table. 
Table 5. Review of the condition of the stability of the VAR

\begin{tabular}{lc}
\hline Root & Modulus \\
\hline 0.831296 & 0.831296 \\
$-0.5344060 .338320 \mathrm{i}$ & 0.632496 \\
$+0.5344060 .338320 \mathrm{i}$ & 0.632496 \\
0.577297 & 0.577297 \\
$-0.378896-0.371162 \mathrm{i}$ & 0.530399 \\
$+0.378896-0.371162 \mathrm{i}$ & 0.530399 \\
-0.521198 & 0.521198 \\
0.165044 & 0.165044 \\
\hline
\end{tabular}

Table 5 indicates whether the results of the estimation of the model VAR stable or stationary. If all the roots of has modulus less than one and the model is stable. All root on the table 5 shows that the roots have modulus less than one so that the VAR model has been stable. Because the Model VAR stable then the results of the forecast for out of sample number of the prevalence of Malaria based on ethnicity presented on the following table.

Table 6. The results of the forecast number of the prevalence of Malaria VAR Model tribal based

\begin{tabular}{|c|c|c|c|c|c|c|c|c|c|}
\hline \multirow{2}{*}{ Year } & \multirow{2}{*}{ Month } & \multicolumn{2}{|c|}{ BANJAR } & \multicolumn{2}{|c|}{ Javaness } & \multicolumn{2}{|c|}{ BUGIS } & \multicolumn{2}{|c|}{ Others } \\
\hline & & actual & forecast & actual & forecast & actual & forecast & actual & forecast \\
\hline 2017 & January & 4 & 6 & 2 & 6 & 1 & 1 & 0 & 0 \\
\hline 2017 & February & 10 & 11 & 4 & 15 & 1 & 3 & 1 & 1 \\
\hline 2017 & March & 41 & 17 & 9 & 9 & 1 & 1 & 0 & 1 \\
\hline 2017 & April & 41 & 36 & 7 & 4 & 2 & 0 & 0 & 0 \\
\hline 2017 & Mei & 0 & 2 & 1 & 1 & 1 & 1 & 0 & 0 \\
\hline \multicolumn{2}{|c|}{ MAPE } & \multicolumn{2}{|c|}{$68 \%$} & \multicolumn{2}{|c|}{$36 \%$} & \multicolumn{2}{|c|}{$8 \%$} & \multicolumn{2}{|c|}{$2 \%$} \\
\hline
\end{tabular}

Table 6 shows that the forecast of the number of the prevalence of malaria in five next period on the tribe of Banjar MAPE value of $68 \%$ (entered in the ability of bad forecasts), on Javanese MAPE value of $36 \%$ (entered in the ability of divination enough), in the tribe of the Bugis provides value MAPE is 8\% (entered in the ability of divination is very good), and on the other tribes provide a 2 percent MAPE value (entered in the ability of divination is very good). The ability of divination number of the prevalence of malaria on the whole of $28.5 \%$, so that entered in the category of good.

\section{CONCLUSIONS}

Based on the results of the analysis that has been done, it can be concluded that the pattern of the number of the prevalence of malaria tends to be uniform from the four tribes, the number of the prevalence of Malaria Javanese there is a relationship with the other tribes and the number of the prevalence of Malaria tribe Bugis with other tribes. VAR Model tribal based on the prevalence of malaria is strong enough to explain the fluctuations in the number of the prevalence of malaria among the tribe. The number of the prevalence of Malaria Javanese influenced by the number of the prevalence of Malaria Javanese at period $\mathrm{t}-1$, and the number of the prevalence of Malaria tribe Bugis at period $\mathrm{t}-1$. While the number of the prevalence of Malaria tribe Bugis influenced by the number of the prevalence of Malaria Other tribes in the period $t-2$. The ability of divination number of the prevalence of malaria on the data out of sample with MAPE criteria provide good results, especially in the tribe of the Bugis and other tribes. 


\section{REFERENCES}

[1] K. Alemu, A. Worku, Y. Berhane, A. Kumie, "Men Traveling Away from Home Are More Likely to Bring Malaria into High Altitude Villages, Nortwest Ethiopia", Public Library of Science (PLoS ONE), vol. 9, 2014.

[2] J.H. Stock, "Vector Autoregressions". Journal of Economic Perspectives. Volume 15. 101-105, 2011.

[3] W.W.S. Wei., Time Series Analysis: Univariate and Multivariate Methods. AddisonWesley Publishing Co., USA, 2006.

[4] D. Gujarati, Basic Econometric, McGraw-Hill, New York, 2003.

[5] A. S. Alisjahbana, L. D. Tuwo, N. Sardjunani, R. S. Prawiradinata, Subandi, Sanjoyo, Hadiat, Darajati, W., Riyati, T., Iryanti, R., Ratman, DR, Jalal, F., Atmawikarta, A., Darmadji, D., Nurdin, MH., Mayangsari, P., Laporan Pencapaian Tujuan Pembangunan Milenium di Indonesia 2011, Kementerian Perencanaan Pembangunan Nasional/Badan Perencanaan Pembangunan Nasional (Bappenas), Jakarta, 2012.

[6] Dinas Kesehatan Propinsi Kalimantan Selatan, Data Bidang Kesehatan Provinsi Kalimantan Selatan Tahun 2012. Banjarmasin: Dinas Kesehatan Propinsi Kalimantan Selatan, 2013.

[7] P. Harijanto, Malaria Epidemiologi, Patogenesis, Manifestasi Klinis, \& Penanganan. Jakarta: Penerbit Buku Kedokteran EGC, 2000.

[8] G. Texier, V. Machault, M. Barragti, J. P. Boutin, C. Rogier, "Environmental Determinant of Malaria Cases Among Travellers", Malaria Journal, pp. 12:87, 2013.

[9] X. Zhao, F. Chen, Z. Feng, X. Li, X. H. Zhou, The temporal lagged association between meteorological factors and malaria in 30 counties in south-west China: a multilevel distributed lag non- linear analysis, 2013.

[10] P. Goswami, U. S. Murty, S. R. Mutheneni, S. T. Krishnan, "Relative Roles of Weather Variables and Change in Human Population in Malaria: Comparison over Different States of India," Public Library of Science (PLoS ONE), 9, 2014.

[11] L. G. Niazyan, "Malaria Risk Stratification in Armenia", Electronic Journal of Natural Sciences, p.2(23), 2014.

[12] K. Bashar, H. M. Al-Amin, M. S. Reza, M. Islam, Asaduzzaman, T. U. Ahmed, "SocioDemographic Factors Influencing Knowledge, Attitude and Practice (KAP) regarding Malaria in Bangladesh", BioMed Central Journal, pp. 12:1084, 2012.

[13] J.C. Berthelemy, J. Thuilliez, O. Doumbo, J. Gaudart, "Malaria and Protective Behaviours: Is There a Malaria Trap?”, Malaria Journal, pp.12:200, 2013.

[14] P. A. West, N. Protopopoff, M. Rowland, E. R. Cumming, A. C. Drakeley, A. Wright, Z. Kivaju, M. J. Kirby, F. W. Mosha, S. Kisinza, I. Kleinschmidt, "Malaria Risk Factors in North West Tanzania: The Effect of Spraying, Nets and Wealth", Public Library of Science (PLoS ONE), vol 8, 2013.

[15] S. J. Moore, S. T. Darling, M. Sihuincha, N. Padilla, G. J. Devine, "A Low-Cost Repellent for Malaria Vectors in The Americas: Results of Two Field Trials in Guatemala and Peru", BMC Journal, pp. 6:101, 2007.

[16] S. Rulisa, F. Kateera, J. P. Bizimana, S. Agaba, J. Dukuzumuremyi, L. Baas, J. D. D. Harelimana, P. F. Mens, K. R. Boer, P. J. D. Vries, "Malaria Prevalence, Spatial Clustering and Risk Factors in a Low Endemic Area of Eastern Rwanda: A Cross Sectional Study", Public Library of Science (PLoS ONE), vol 8, 2013. 
[17] J. X. Liu, T. Bousema, B. Zelman, S. Gesase, R. Hashim, C. Maxwell, D. Chandramohan, R. Gosling, "Is Housing Quality Associated with Malaria Incidence among Young Children and Mosquito Vector Numbers? Evidence from Korogwe, Tanzania", Public Librarry of Science (PLoS ONE), vol 9, 2014.

[18] M. Mora-Ruíz, R. P. Penilla, J. G. Ordóñez, A. D. López, F. Solis, J. L. Torres-Estrada, A. D. Rodríguez, "Socioeconomic factors, attitudes and practices associated with malaria prevention in the coastal plain of Chiapas, Mexico", Malaria Journal, pp. 13:157, 2014.

[19] O. Onwujekwe, E. Etiaba, N. Uguru, B. Uzochukwu, A. Adjagba, "Towards making efficient use of household resources for appropriate prevention of malaria: investigating households ownership, use and expenditures on ITNs and other preventive tools in Southeast Nigeria", BMC Journal, pp. 14:315, 2014.

[20] K. Shkurti, G. Vyshka, E. Velo, A. Boçari, M. Kokici, D. Kraja, "Imported Malaria in Albania and The Risk Factors That Could Allow its Reappearance", Malaria Journal, pp. 12:197, 2013.

[21] X. F. Niu, I. W, McKeague, J. B. Elsmer, "Improving Climate Prediction Using Seasonal Space-Time Models", 1996.

[22] N. D. Gumanti, Sutikno, Setiawan, Penerapan Metode GSTAR dengan Pendekatan Spatio-Temporal untuk Memodelkan Kejadian Demam Berdarah. FMIPA ITS, 2010.

[23] M. Pahrudin, Spatio-Temporal Modeling untuk Prediksi Kasus Malaria dan Manajemen Pengendaliannya di Kabupaten Tanah Bumbu Propinsi Kalimantan Selatan. Tesis. FKM Unair, Surabaya, 2013.

[24] A. Khair, Sarmanu, M. Santi, B. W. Otok., "The Modeling of Malaria Cases Tribal Based in Tanah Bumbu Using Space Time Autoregressive", J. Appl. Environ. Biol. Sci., vol. 7(10), pp. 214-219, 2017.

[25] P. E. Pfeifer and S. J. Deutsch, "A Three Stage Iterative Procedure for Space Time Modelling", Technometrics, vol. 22 (1), pp. 35-47, 1980.

[26] H.P. Lopuhaa, Space Time Autoregressive Models. Delft University of Technology. Jerman, 2002. 